\title{
Effects of resuspension and mixing on population dynamics and trophic interactions in a model benthic microbial food web
}

\author{
Tobias Garstecki* ${ }^{*}$ Stephen A. Wickham
}

University of Cologne, Zoological Institute, General Ecology and Limnology, Weyertal 119, 50923 Cologne, Germany

\begin{abstract}
The effects of resuspension and mixing on the population dynamics and trophic interactions in a simple benthic microbial food web were studied during 3 plankton wheel experiments of 9 to $15 \mathrm{~d}$ duration. The food web consisted of a mixed bacterial assemblage, the heterotrophic flagellate Bodo designis, the ciliate Euplotes balteatus and the rhizopod Vannella platypodia. The diatom Amphora coffeaeformis was included to maintain oxygen concentrations. B. designis, E. balteatus, $V$. platypodia and A. coffeaeformis are hereafter referred to by genus name alone. Population dynamics in $500 \mathrm{ml}$ microcosms on rotating and non-rotating plankton wheels were compared. Final abundances of Amphora increased in suspension in all experiments. Resuspension increased initial growth rates and final abundances of Euplotes and Vannella during a whole-community experiment and a community subset experiment during which resuspension effects with and without the top predator Euplotes were compared. During the community subset experiment, suspended Bodo grew faster and reached higher final abundances than non-resuspended Bodo when Euplotes was absent, but experienced higher loss to Euplotes when the ciliate was present. Individual consumption rates of Bodo by Euplotes were estimated to be higher in suspension (5.5 vs 3.6 Bodo Euplotes ${ }^{-1} \mathrm{~h}^{-1}$ ), which could not be explained by higher abundance of Bodo alone. Similar but non-significant trends were found for bacteria. During a third experiment, Euplotes did not benefit from resuspension at low food concentrations. Our results show that resuspension and mixing can enhance population growth of autotrophic and heterotrophic protists, and that the trophic coupling between flagellates and ciliates, and possibly between other microbial food web components, can become closer in suspension when the food supply is sufficient. This suggests that subsidiary energy input by resuspension and mixing may increase the biomass turnover in benthic microbial food webs.
\end{abstract}

KEY WORDS: Resuspension - Microbial food web · Trophic interactions · Growth enhancement · Ciliates $\cdot$ Rhizopods $\cdot$ Flagellates

Resale or republication not permitted without written consent of the publisher

\section{INTRODUCTION}

The sediment and water column of shallow lakes and coastal waters are closely coupled by sedimentation and wind- or tide-induced sediment resuspension. Together with resuspended sediments, bacteria, microphytobenthos and heterotrophic protists enter the water column during resuspension events (Shaffer

\footnotetext{
${ }^{*}$ Present address: Natural Environment Research Council, British Antarctic Survey, High Cross, Madingley Road, Cambridge CB3 0ET, United Kingdom.

E-mail: tga@pcmail.nerc-bas.ac.uk
}

\& Sullivan 1988, Padišak et al 1990, De Jonge \& Van Beusekom 1992, 1995, Arfi \& Bouvy 1995, Shimeta \& Sisson 1999, Garstecki et al. 2000). Although benthic protists can contribute substantially to water column abundances in the field (Shaffer \& Sullivan 1988, De Jonge \& Van Beusekom 1992, Garstecki et al. 2000), the effects of resuspension and mixing on resuspended protists and on the benthic microbial food web as a whole have not been studied. Instead, experimental studies of microbial responses to resuspension have shown important effects of released nutrients and organic carbon on plankton: phytoplankton can benefit from nutrients imported with resuspended sedi- 
ments (Kristensen et al. 1992, Reynolds 1996, Ogilvie \& Mitchell 1998). The same is true for bacterioplankton (Wainright 1987, Jugnia et al. 1998) and heterotrophic nanoplankton (Wainright 1987).

The kinetic energy of wind and tides may favour plankton organisms through water column mixing and turbulence (e.g., Aguilera 1994, Peters \& Gross 1994, Shimeta et al. 1995). Similarly, sediment resuspension and mixing should not only resuspend buried nutrients but also increase the total surface area of suspended particulates and alter encounter rates between predators and prey. Dilution of populations inhabiting resuspended sediments should decrease encounter rates, while mixing should increase them. This should result in increased bacterial growth and altered trophic coupling in resuspended benthic microbial food webs. As a first experimental test of this hypothesis, we have studied the effects of resuspension and mixing on a simple, artificially assembled benthic microbial food web. Although the experiments were designed to identify general mechanisms of resuspension on the microbial community, we have chosen benthic organisms that have previously been found in suspension in shallow inlets of the southern Baltic and in other shallow coastal waters (Zimmermann-Timm et al. 1998, Garstecki et al. 2000).

\section{MATERIALS AND METHODS}

Model community. The model benthic microbial community consisted of a natural mixed bacterial assemblage, the diatom Amphora coffeaeformis (length $=25 \mu \mathrm{m}$ ), the bacterivorous flagellate Bodo designis (length $=8 \mu \mathrm{m}$ ), the omnivorous ciliate Euplotes balteatus (length $=70 \mu \mathrm{m}$ ) and the presumably bacterivorous rhizopod Vannella platypodia (length $=15 \mu \mathrm{m}$, Expts 1 and 2 only). B. designis, E. balteatus, V. platypodia and A. coffeaeformis are hereafter referred to by genus name alone. Representatives of the genera Bodo, Euplotes and Vannella have been found in the water column of coastal waters during resuspension events (Garstecki et al. 2000, Zimmermann-Timm et al. 1998). The bacterial assemblage and all heterotrophic protists were isolated from sediments of Rassower Strom, coastal southern Baltic. Sediment aliquots were inoculated into Føyns-Erdschreiber medium (Page \& Siemensma 1991). Protists were further isolated by dilution until all other eukaryotes were absent. Bacteria were separated from protists by filtration with a $0.8 \mu \mathrm{m}$ polycarbonate membrane filter. The diatom Amphora was too large to be ingested by the other protists. It was included to maintain the oxygen concentration within the experimental bottles and to foster bacterial growth by exudation.
All stock cultures were kept at $18^{\circ} \mathrm{C}$ in FøynsErdschreiber medium, prepared with 10 PSU artificial seawater (ASW; Caron 1993). Illumination was $15 \mu \mathrm{mol}$ $\mathrm{m}^{-2} \mathrm{~s}^{-1}$ PAR photon flux density (LI-COR quantum sensor, Biosciences, Lincoln, NB), with a light/dark cycle of $15 / 9 \mathrm{~h}$.

Experimental design. The population dynamics of identical communities incubated together with autoclaved surface sediments on rotating and non-rotating plankton wheels were compared during 3 planktonwheel experiments (Table 1). These consisted of a whole-community experiment with liquid organic enrichment, and 2 semi-continuous experiments, 1 with liquid organic enrichment and 3 different community subsets (community subset experiment), and 1 with identical communities but with or without particulate organic enrichment (particulate enrichment experiment). The experiments were carried out using vertical plankton wheels (1.2 m diameter). When rotating, the plankton wheels kept sediment and benthic organisms in suspension. The whole-community experiment was carried out to follow the overall dynamics of the microbial community in resuspended sediment. The microcosms were enriched once at the beginning of the experiment with Føyns-Erdschreiber medium $(5 \%)$ to simulate nutrient and organic carbon pulses during resuspension events. During the community subset experiment we analysed how trophic interactions are affected by resuspension. The population dynamics of bacteria and nanofauna (Bodo and Vannella) with and without their respective predators (all heterotrophic protists in the case of bacteria and Euplotes in the case of Bodo) were followed, allowing estimates of loss rates due to predation in resuspended and non-resuspended communities. The particulate enrichment experiment was designed to distinguish resuspension effects mediated by an import of edible organic matter into the water column from resuspension effects without enrichment. Urtica powder was used to simulate particulate phytodetritus in this experiment.

Inoculation and incubation. Aliquots of the inocula were inoculated into 24 acid-rinsed $500 \mathrm{ml}$ polycarbonate bottles containing 10 PSU ASW, $0.4 \mathrm{~g} \mathrm{l}^{-1}$ doublesterilised, washed surface sediment from Rassower Strom and enrichment (Table 1). Before the wholecommunity experiment, an additional 4 flasks were prepared in the same way and sampled at $t_{0}$. The individual cultures for the community subset experiment were inoculated separately (Table 1). In this experiment, aliquots of $2 \mu \mathrm{m}$ filtered cultures of Vannella, Bodo and Euplotes were pipetted into those bottles not receiving the respective inoculates. This was done to minimise differences in initial bacterial abundance due to bacteria co-inoculated with the protistan cul- 
Table 1. Inocula, enrichments, initial abundances and sampling schedules. Each group in the community subset experiment and in the particulate enrichment experiment consisted of 4 resuspended and 4 control replicate bottles. Twelve control, 12 resuspended and $4 t_{0}$ bottles were used in the whole-community experiment

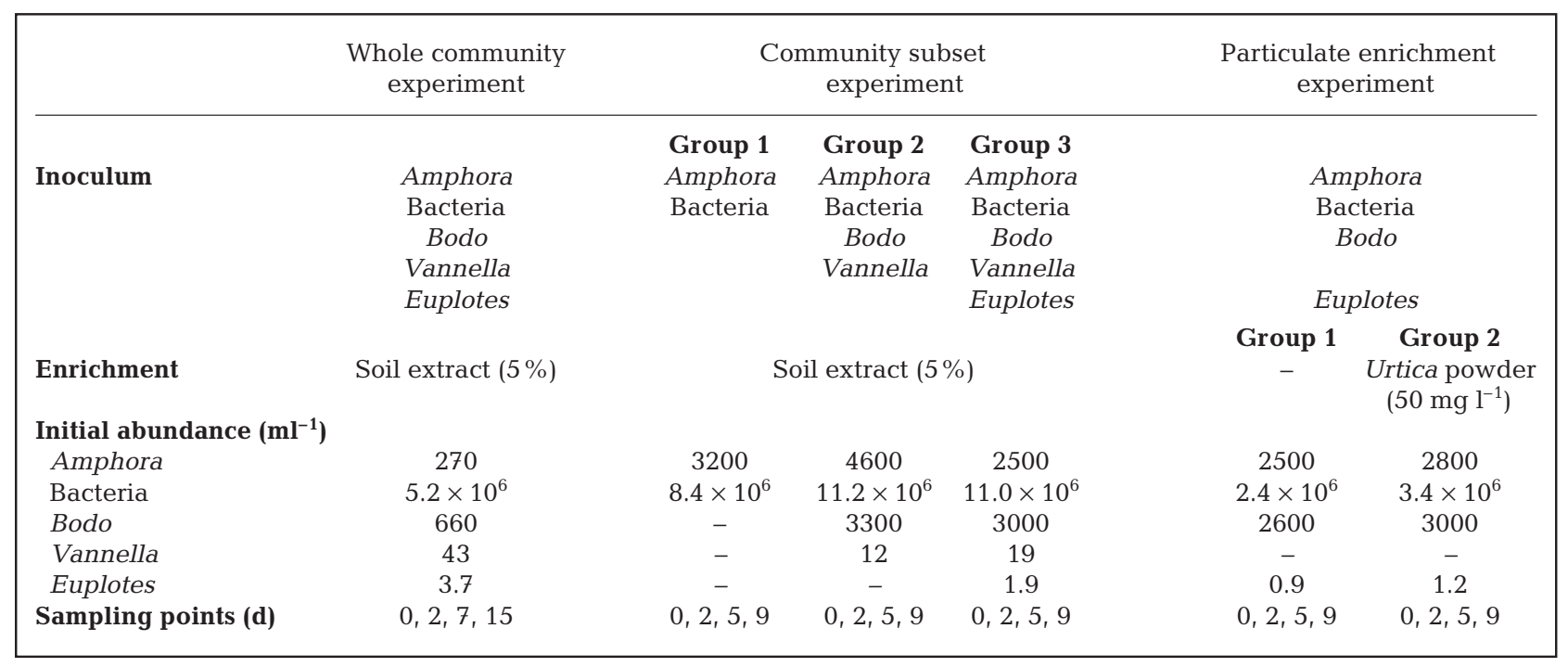

tures. The initial abundances of bacteria, Bodo, Vannella and Euplotes were within the naturally occurring abundance range of the respective groups in the coastal southern Baltic (Garstecki et al. 2000). When closing the incubation bottles after inoculation, care was taken to prevent air bubbles from being trapped inside the bottles.

Eight or 12 bottles each were randomly mounted on 2 plankton wheels. In the whole-community experiment, all bottles received an identical inoculum. In the community subset experiment and in the particulate enrichment experiment, each wheel carried 2 or 3 groups of 4 replicate bottles, each group containing different community subsets or different enrichment levels. The plankton wheel carrying the resuspended microcosms rotated at $5 \mathrm{rpm}$, which was sufficient to keep the sediments in suspension. The wheel carrying the control microcosms only was turned once a day, by $180^{\circ}$, to correct for differences in light intensity on its upper and lower sides. The bottles mounted on the plankton wheels were incubated at $18^{\circ} \mathrm{C}$ and $15 \mu \mathrm{mol} \mathrm{m} \mathrm{m}^{-2} \mathrm{~s}^{-1}$ photon flux density (light/dark cycle 15/9 h) for $15 \mathrm{~d}$ (whole-community experiment) or $9 \mathrm{~d}$ (community subset experiment and particulate enrichment experiment).

Sampling and sample analysis. Before each sampling (Table 1), the bottles were extensively shaken and oxygen concentrations within the bottles were measured. Samples for the enumeration of bacteria, Amphora, Bodo, Vannella and Euplotes were taken. During the whole-community experiment, 4 replicate bottles were removed and sampled from each plankton wheel at each sampling occasion, whereas $100 \mathrm{ml}$ of culture medium was sampled from each bottle at each occasion during both semi-continuous experiments. Sample volumes were replaced with a cocktail of ASW, sediment and enrichment at concentrations equal to the initial concentrations in the respective bottles.

Oxygen concentrations were measured with an oxygen probe (WTW GmbH \& Co. KG, Weilheim, Germany). Bacteria and Bodo were fixed with glutaraldehyde (1.5\% final concentration) and enumerated in DAPI-stained samples using epifluorescence microscopy (Sherr et al. 1993). Briefly, $0.5 \mathrm{ml}$ and $2 \mathrm{ml}$ subsamples were stained $\left(2.5 \mu \mathrm{g} \mathrm{ml}^{-1}\right.$ final DAPI concentration) and concentrated on black polycarbonate filters (Millipore Corp., Bedford, MA) of 0.2 and $0.8 \mu \mathrm{m}$ pore size for the enumeration of bacteria and Bodo, respectively. At least 50 Bodo and 300 bacteria on a minimum of 50 and 15 grids, respectively, were counted. In addition, the presence of picoautotrophs was checked based on chlorophyll autofluorescence at 450 to $490 \mathrm{~nm}$ excitation. Vannella was enumerated with a modified version of the liquid aliquot method (Garstecki \& Arndt 2000). Between 24 and 72 subsamples of 1 to $100 \mu \mathrm{l}$ were inoculated into wells of tissue culture plates containing Føyns-Erdschreiber medium. After 14 d incubation at $18^{\circ} \mathrm{C}$ in the dark, the wells were screened for the presence of Vannella and initial abundances were calculated from the frequency of positive wells assuming a Poisson distribution. Euplotes and Amphora were fixed in Bouin's fixative (a mixture of $80 \%$ formaldehyde saturated with picric acid and $20 \%$ acetic acid at $5 \%$ final concentration) and counted after sedimentation of $10 \mathrm{ml}$ subsamples according to Utermöhl (1958). During the community subset experiment, aliquots of $1 \mathrm{ml}$ from each ciliate-free microcosm were incubated in sterile 
vials containing ASW enriched with soil extract and subsequently monitored for contamination with any heterotrophic protists (protist-free group) or Euplotes (Euplotes-free group).

Statistical analysis. Abundances were corrected for after-sampling replacement dilution in both semi-continuous experiments. Initial exponential growth rates were calculated from mean group abundances at $t_{0}$ and at $2 \mathrm{~d}$, the first 2 samping points. When appropriate during the community subset experiment, loss rates due to predation were estimated from the difference in growth rate with and without predators present. Individual consumption rates of Euplotes were estimated from these loss rates, initial prey abundances and geometric mean predator abundances.

The significance of effects of time, resuspension, predators (community subset experiment only) and enrichment (particulate enrichment experiment only) was tested with log-transformed data using 2-way ANOVA (whole community experiment) or 2-way repeated measures ANOVA (RM-ANOVA; community subset and particulate enrichment experiment). The data were log-transformed for the tests because the variance differed between treatments, but the untransformed data are given in the figures. The significance of resuspension effects at individual sampling occasions was tested using unpaired $t$-tests, with Bonferroni corrections for the number of sampling occasions applied to the significance thresholds. Spearman's rank correlation coefficients between microbial abundances at all sampling occasions were calculated to gauge the degree of coupling within the microbial communities. All statistical procedures were carried out using SPSS (SPSS Inc., Chicago, IL).

\section{RESULTS}

\section{Whole-community experiment}

During the whole-community experiment, clear resuspension effects were found on several levels of the model microbial food web (Fig. 1). Euplotes showed a dramatic increase in abundance that was even greater in the resuspended bottles, but these effects were apparent only on the last sampling date $(68.0 \pm 5.1$ and $28.1 \pm 15.0$ ind. $\mathrm{ml}^{-1}$, resuspended and control microcosms, respectively, $\mathrm{p}=0.016$; Fig. 1e). Vannella also grew rapidly in both the resuspended and the control

Fig. 1. Abundances of (a) Amphora, (b) bacteria, (c) Bodo, (d) Vannella and (e) Euplotes during the whole-community experiment (mean $\pm \mathrm{SD}, \mathrm{N}=4$ ). ${ }^{*} \mathrm{p}<0.05$, $t$-test, Bonferroni corrected a)

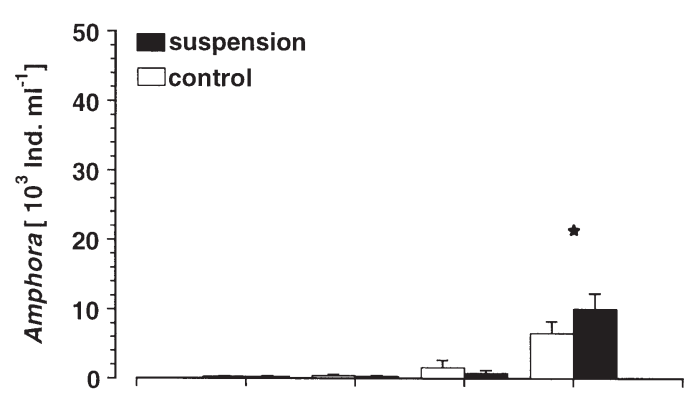

b)

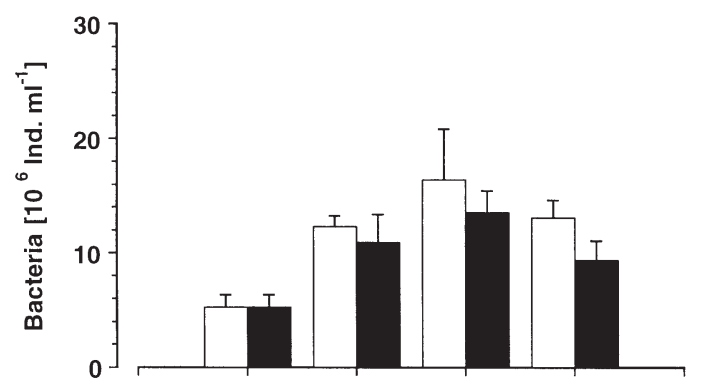

c)

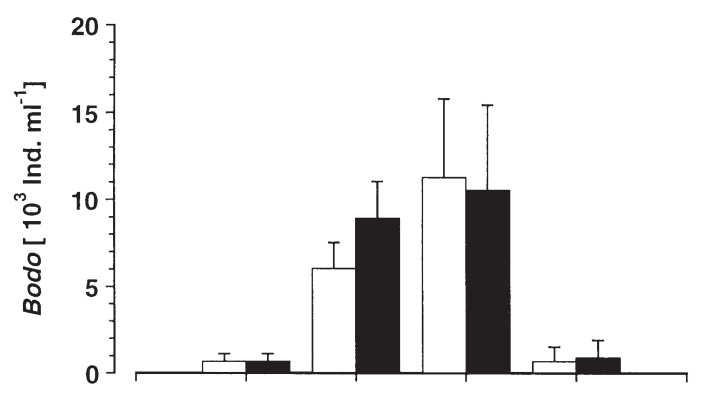

d)

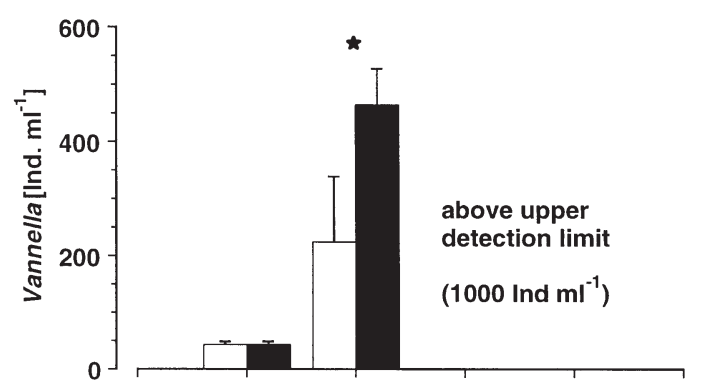

e)

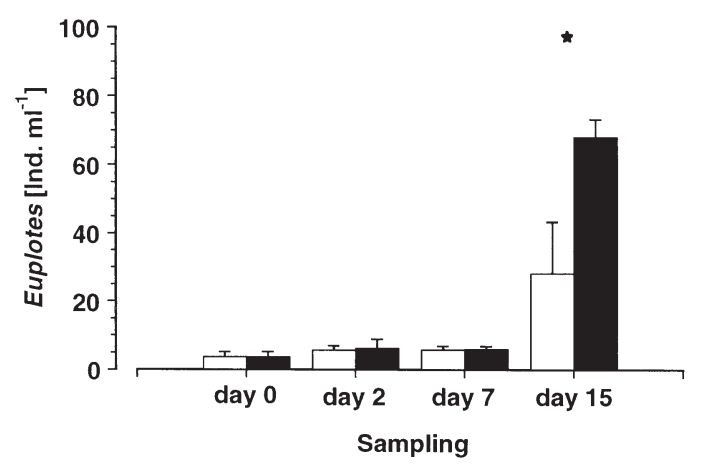


bottles (Table 2, Fig. 1d). They exceeded the upper detection limit of the cultivation method (1000 ind. $\mathrm{ml}^{-1}$ ) after $5 \mathrm{~d}$. However, their abundances were already significantly higher in the resuspended microcosms than in the controls after $2 \mathrm{~d}(465 \pm 62$ and $224 \pm$ 115 ind. $\mathrm{ml}^{-1}, \mathrm{p}=0.016$ ). Similar to Euplotes, Amphora showed an initial growth lag and was more abundant in the resuspended microcosms at the end of the experiment $\left(10.1 \pm 2.2 \times 10^{3}\right.$ and $6.6 \pm 1.7 \times 10^{3}$ ind . $\mathrm{ml}^{-1}, \mathrm{p}=0.025$; Fig. 1a). Bacteria showed no significant resuspension effect (Fig. 1b). Bodo increased until Day 7 (maximum $11.3 \times 10^{3}$ ind. $\mathrm{ml}^{-1}$ in the control microcosms) and had declined by Day 15. Positive resuspension effects on initial growth rates (Table 2) did not result in significant differences in abundance at the end of the experiment (Fig. 1c).

Spearman's correlation coefficients suggest that population dynamics within the microbial community were related to each other in a complex manner: the abundances of Amphora and Euplotes were positively correlated over the whole course of the experiment $(\mathrm{p}<0.01)$, while flagellate abundances were negatively correlated to those of the former groups $(\mathrm{p}<$ 0.01). Rhizopods were not included in this correlation analysis because they were counted only at the first 2 sampling occasions.

\section{Community subset experiment}

The general trends of the whole-community experiment were also found in the community subset experiment. Growth of Amphora lagged initially and was enhanced in suspension irrespective of microbial com-

Table 2. Mean initial growth rates of microbial populations in the community subset experiment (calculated from abundances on Day 0 and Day 2)

\begin{tabular}{|lcccc|}
\hline Treatment & $\begin{array}{c}\text { Bacteria } \\
\left(\mathrm{d}^{-1}\right)\end{array}$ & $\begin{array}{c}\text { Bodo } \\
\left(\mathrm{d}^{-1}\right)\end{array}$ & $\begin{array}{c}\text { Vannella } \\
\left(\mathrm{d}^{-1}\right)\end{array}$ & $\begin{array}{c}\text { Euplotes } \\
\left(\mathrm{d}^{-1}\right)\end{array}$ \\
\hline Whole community & & & & \\
Control & 0.43 & 1.11 & 0.91 & 0.20 \\
Suspension & 0.37 & 1.30 & 1.28 & 0.30 \\
Community subset & & & & \\
Control & 0.44 & - & - & - \\
Suspension & 0.40 & - & - & - \\
Control + nanofauna & 0.23 & 0.20 & 0.47 & - \\
Suspension + nanofauna & 0.27 & 0.27 & 0.92 & - \\
Control + all protists & 0.16 & 0.10 & 0.42 & 0.12 \\
Suspension + all protists & 0.16 & 0.06 & 0.53 & 0.39 \\
Particulate enrichment & & & & \\
Control & 0.24 & 0.24 & - & 0.47 \\
Suspension & 0.15 & 0.25 & - & 0.03 \\
Control + enrichment & 0.27 & 0.46 & - & 0.25 \\
Suspension + enrichment & 0.27 & 0.53 & - & 0.43 \\
\hline
\end{tabular}

Table 3. p-values for protistan and suspension effects over time and their interactions within the repeated measures (RM)-ANOVA design of the community subset experiment $(\mathrm{N}=4)$. Prot.: protist presence; Susp.: suspension. * Presence of no protists, only Vannella and Bodo, or all protists in the case of Amphora and bacteria ( $2 \times 3$ RM-ANOVA), presence or absence of Euplotes in the case of Bodo and Vannella $(2 \times 2$ RMANOVA). Values in bold show statistically significant results

\begin{tabular}{|lrrrr|}
\hline & Amphora & Bacteria & Bodo & Vannella \\
\hline Susp. & $\mathbf{0 . 0 1 1}$ & 0.819 & $\mathbf{0 . 0 2 4}$ & $<\mathbf{0 . 0 0 1}$ \\
Prot. $^{*}$ & 0.811 & $<\mathbf{0 . 0 0 1}$ & $<\mathbf{0 . 0 0 1}$ & 0.367 \\
Time & $<\mathbf{0 . 0 0 1}$ & $<\mathbf{0 . 0 0 1}$ & $<\mathbf{0 . 0 0 1}$ & $<\mathbf{0 . 0 0 1}$ \\
Susp. $\times$ Prot. & 0.429 & 0.333 & $\mathbf{0 . 0 1 8}$ & 0.658 \\
Susp. $\times$ Time & $<\mathbf{0 . 0 0 1}$ & 0.763 & 0.105 & $\mathbf{0 . 0 0 2}$ \\
Prot. $\times$ Time & $\mathbf{0 . 0 1 5}$ & 0.114 & 0.771 & $\mathbf{0 . 0 3 4}$ \\
Susp. $\times$ Prot. $\times$ Time & 0.125 & 0.627 & 0.976 & $\mathbf{0 . 0 0 6}$ \\
\hline
\end{tabular}

munity structure (RM-ANOVA, Fig. 2, Table 3). In contrast, no significant protistan effects on diatom abundance were found. Final diatom abundances ranged from $6.7 \pm 2.1 \times 10^{3}$ ind. $\mathrm{ml}^{-1}$ in the control microcosms with nanofauna only (Fig. $2 b$ ) to $33.1 \pm 12.8 \times 10^{3}$ ind. $\mathrm{ml}^{-1}$ in the resuspended whole-community microcosms (Fig. 2c).

Similar to the whole-community experiment, Euplotes tended to grow faster in the resuspended microcosms (Fig. 3, Table 2). The final difference in abundance $\left(75.7 \pm 15.8\right.$ and $65.1 \pm 19.8$ ind. $\mathrm{ml}^{-1}$, resuspended and control microcosms, respectively) was not significant in this experiment, however.

In the absence of ciliates, both Bodo and Vannella tended to grow faster in suspension (Fig. 4, Table 2). The final difference in abundance was significant for the flagellates $\left(12.9 \pm 2.6 \times 10^{3}\right.$ and $6.9 \pm 2.6 \times 10^{3}$ ind. $\mathrm{ml}^{-1}$, resuspended and control microcosms, respectively, $\mathrm{p}=0.024$; Fig. $4 \mathrm{a}$ ) but not for the rhizopods $\left(284 \pm 70\right.$ and $189 \pm 83$ ind $\mathrm{ml}^{-1}$ i Fig. 4c). In the presence of Euplotes, net growth rates of Bodo were less and lower in suspension than in the controls (Table 2). There was no significant difference in final abundance of Bodo in resuspended and control microcosms in the presence of Euplotes (Fig. 4b). The RM-ANOVA of flagellate abundance revealed both significant main effects of ciliate presence and resuspension, and a significant interaction between both factors (Table 3). Estimated individual grazing rates of Euplotes on Bodo were high during the first $2 \mathrm{~d}$ of the experiment (3.6 and 5.5 Bodo Euplotes $^{-1} \mathrm{~h}^{-1}$, control and resuspended microcosms, respectively) and declined to $<0.1$ Bodo Euplotes ${ }^{-1} \mathrm{~h}^{-1}$ towards the end of the experiment when the average ratio of flagellate to ciliate abundance dropped below $10^{3}$. 

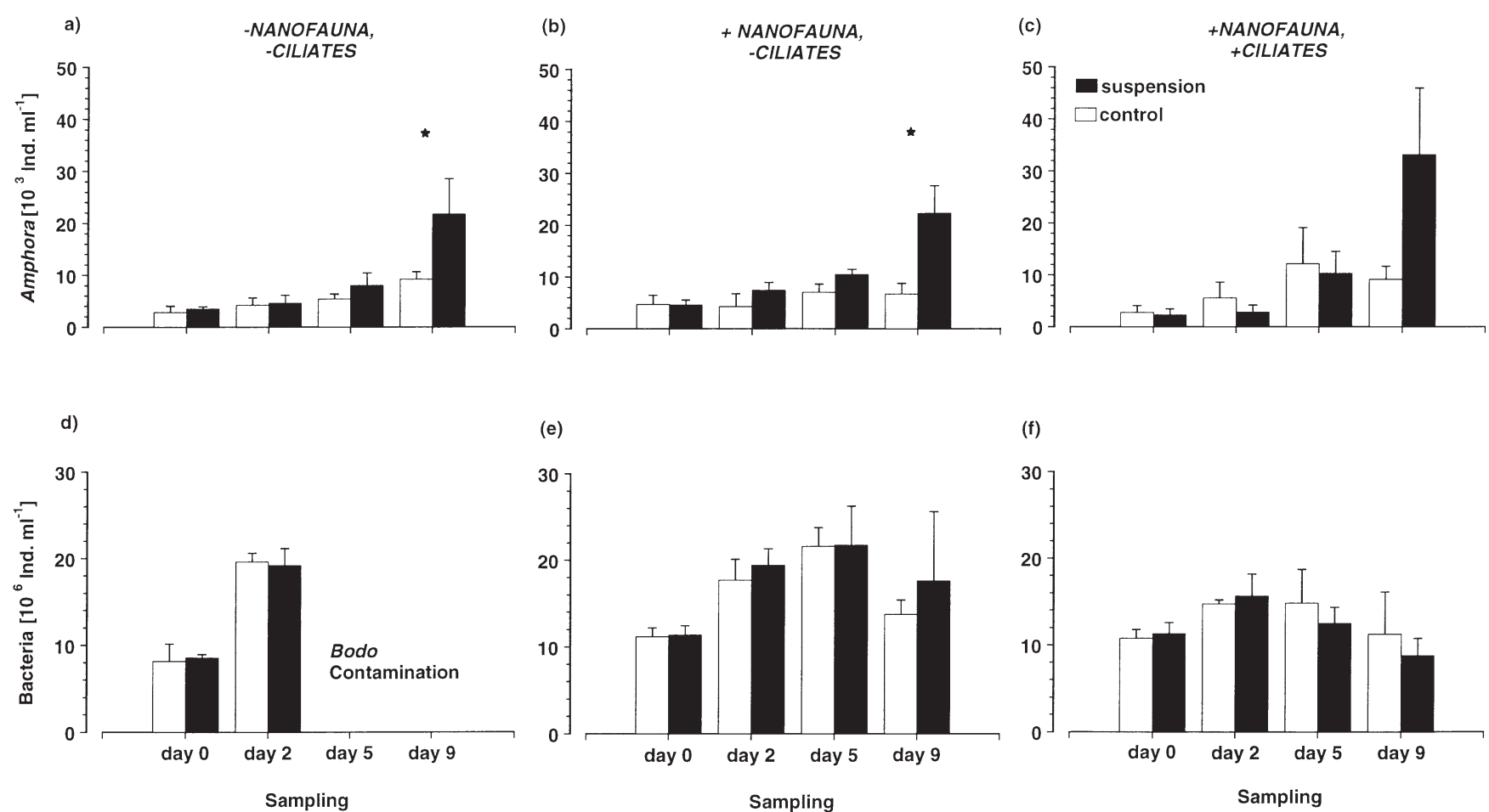

Fig. 2. Abundances of (a to c) Amphora and (d to f) bacteria during the community subset experiment (mean $\pm \mathrm{SD}, \mathrm{N}=4$ ). ${ }^{*} \mathrm{p}<0.05, t$-test, Bonferroni corrected. The scale for the $y$-axis is the same in the 3 experimental treatments

Vannella growth showed stronger positive resuspension effects in the presence of Euplotes, reaching $459 \pm$ 113 ind. $\mathrm{ml}^{-1}$ at the end of the experiment, and significantly exceeding the abundances in the non-resuspended microcosms $\left(182 \pm 53\right.$ ind. $\mathrm{ml}^{-1}, \mathrm{p}=0.012$; Fig. 4d). The RM-ANOVA of rhizopod abundances showed a highly significant positive resuspension effect, but no effect of ciliate presence and no interaction (Table 3).

Resuspension did not significantly affect bacterial abundance in any treatment combination (Fig. 2, Table 3). After $2 \mathrm{~d}$, most of the protist-free microcosms were contaminated with Bodo. Therefore, the initially

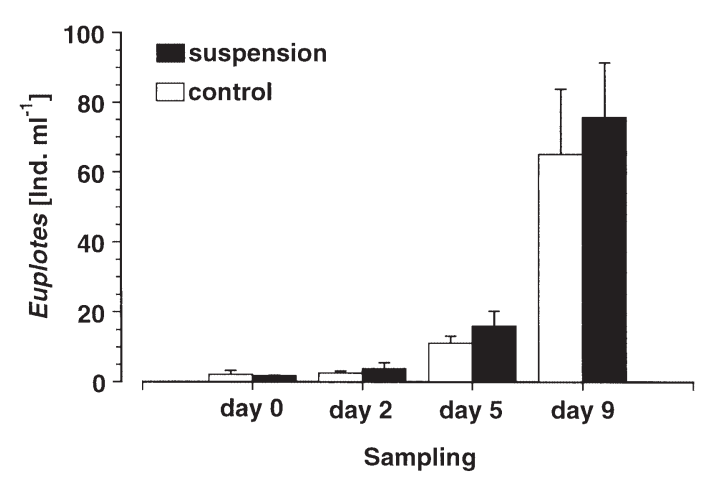

Fig. 3. Abundance of Euplotes during the community subset experiment (mean $\pm \mathrm{SD}, \mathrm{N}=4$ ) bacterivore-free group was excluded from further analysis. Treatments with ciliates had significantly fewer bacteria than those with only nanofauna or bacteria alone (Fig. 2f, Table 3). Although no grazing rates of Euplotes on bacteria could be calculated from our experiment, mean loss rates to bacterivores were much higher in the presence of all protists including Euplotes $\left(-0.26 \mathrm{~d}^{-1}\right)$ than in the presence of Bodo and Vannella alone $\left(-0.18 \mathrm{~d}^{-1}\right)$, suggesting that Euplotes had a strong grazing impact on bacteria.

In those microcosms where all eukaryotes were present, their abundances were significantly positively correlated to each other over the whole course of the experiment. Bacterial abundances were positively correlated to those of Bodo only (Table 4). Correlations between Amphora, Vannella and Euplotes were stronger in suspension, while correlations between bacteria on one hand and Vannella and Euplotes on the other were switched from positive to negative (data not shown). In microcosms without Euplotes, all microbial populations were significantly positively correlated to each other (Table 4).

\section{Particulate enrichment experiment}

Urtica powder had a negative growth effect on Amphora (Fig. 5a,b, Table 5), but growth was again 
a)

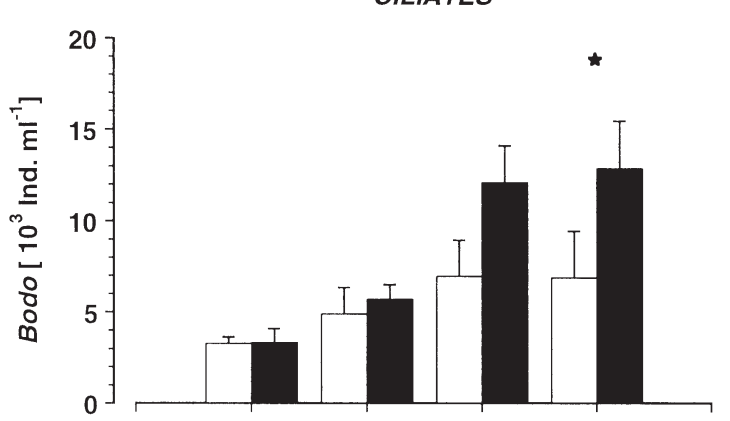

c)

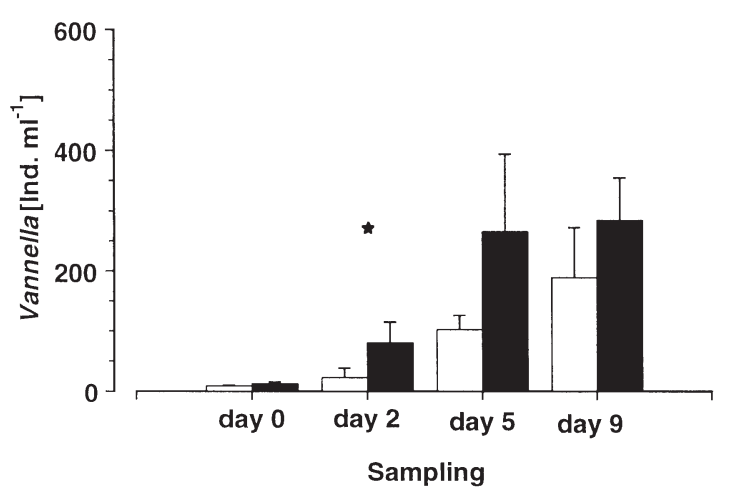

(b)

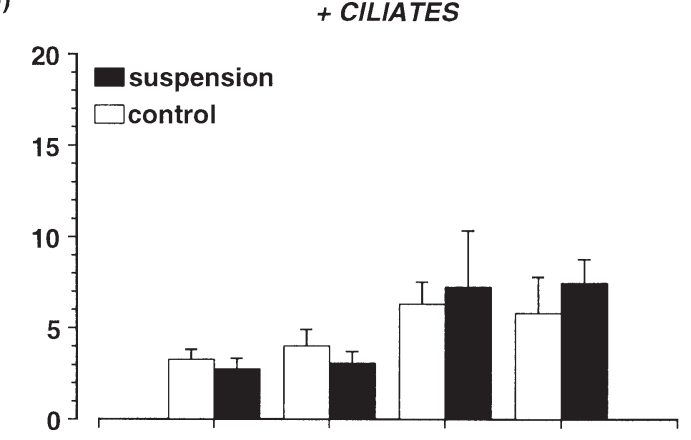

(d)

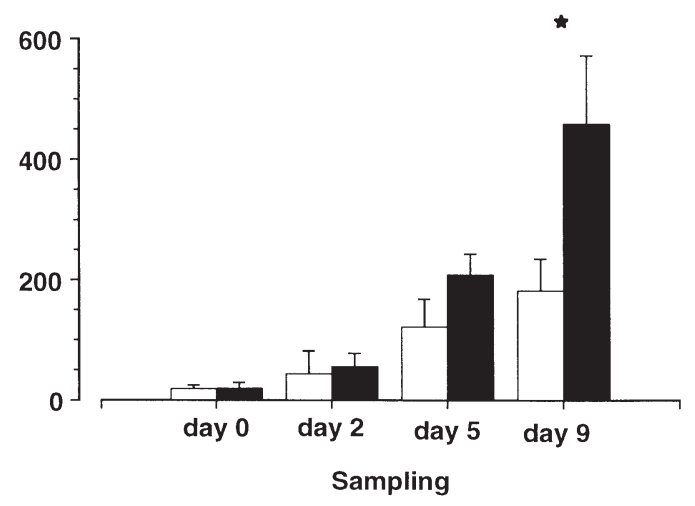

Fig. 4. Abundances of $(\mathrm{a}, \mathrm{b})$ Bodo and (c,d) Vannella in the presence (+ Ciliates) and in the absence (- Ciliates) of Euplotes during the community subset experiment (mean $\pm \mathrm{SD}, \mathrm{N}=4$ ). ${ }^{*} \mathrm{p}<0.05, t$-test, Bonferroni corrected. The scale for the $y$-axis is the same in both experimental treatments

fostered by resuspension in the non-enriched microcosms. Resuspension increased mean final diatom abundance in minimal medium by a factor of 3 compared with the final abundance in the non-resuspended controls $\left(37.9 \pm 5.8 \times 10^{3}\right.$ and $11.6 \pm 2.9 \times 10^{3}$ ind. $\mathrm{ml}^{-1}, \mathrm{p}=0.004$; Fig. 5a). Abundances of bacteria and Bodo were not affected by resuspension (Tables 2 \& 5).

Compared with the minimal medium, particulate enrichment increased the final abundance of Euplotes (Fig. 5g,h, Table 5). Resuspension had a positive, time-dependent effect on ciliate growth and abundance, but only in the particle-enriched microcosms (final abundances of $25.5 \pm 1.2$ ind. $\mathrm{ml}^{-1}$ in suspension and $16.0 \pm 3.3$ ind. $\mathrm{ml}^{-1}$ in the controls, $\mathrm{p}=0.012$; Fig. $5 \mathrm{~h}$ ). It had a negative effect in minimal medium (final abundances of $6.9 \pm 0.9$ ind. $\mathrm{ml}^{-1}$ in suspension and $11.0 \pm 1.9$ ind. $\mathrm{ml}^{-1}$ in the controls, $\mathrm{p}=0.028$; Fig. 5g) This resulted in a significant interaction between particulate enrichment and resuspension in the RMANOVA (Table 5).

The abundances of Amphora, bacteria and Euplotes were positively correlated over the whole course of the particulate enrichment experiment (Spearman's r, p < 0.01), but neither enrichment nor resuspension had effects on these correlations. An exception to this trend was the decoupling of bacteria and Amphora in the enriched microcosms by resuspension (Spearman's $r$ without suspension 0.682, $\mathrm{p}<0.004$; in suspension 0.433, $\mathrm{p}=0.094$ ).

No effects of resuspension, community structure or enrichment on oxygen concentrations in the microcosms or on the size or shape of any organisms were found in any experiment. This was also true for the bacteria, which were dominated by rods of 1 to $2 \mu \mathrm{m}$ length in all treatments. No picoautotrophs were present. Table 6 summarises resuspension effects on the final abundances of microbial food web components.

Table 4. Correlations between microbial abundances during the community subset experiment. Correlation coefficients for the whole community microcosms are given in the lower lefthand corner while those for the ciliate-free microcosms are given in the upper right-hand corner. Spearman's $\mathrm{r}_{i}{ }^{*} \mathrm{p}<0.05$; ${ }^{* *} \mathrm{p}<0.01$ )

\begin{tabular}{|lcccc|}
\hline & Amphora & Bacteria & Bodo & Vannella \\
\hline Amphora & - & $0.396^{*}$ & $0.575^{* *}$ & $0.763^{* *}$ \\
Bacteria & -0.077 & - & $0.915^{* *}$ & $0.482^{* *}$ \\
Bodo & $0.362^{*}$ & $0.793^{* *}$ & - & $0.693^{* *}$ \\
Vannella & $0.704^{* *}$ & -0.173 & $0.405^{*}$ & - \\
Euplotes & $0.783^{* *}$ & -0.103 & $0.478^{* *}$ & $0.893^{* *}$ \\
\hline
\end{tabular}


a)

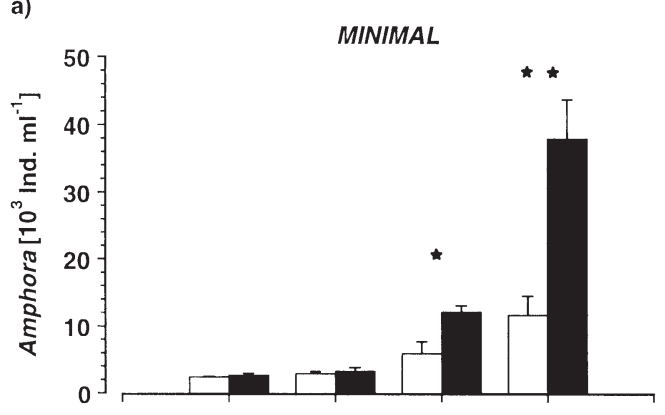

c)

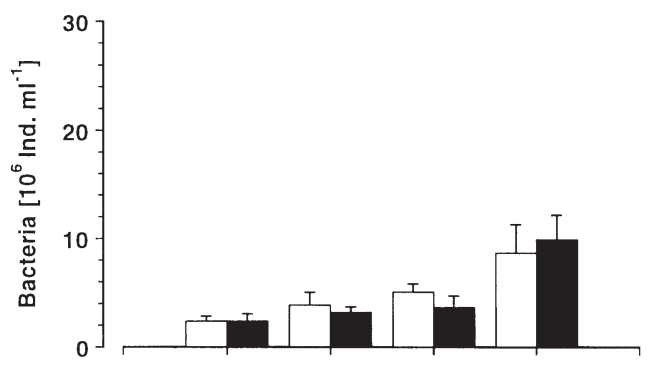

e)

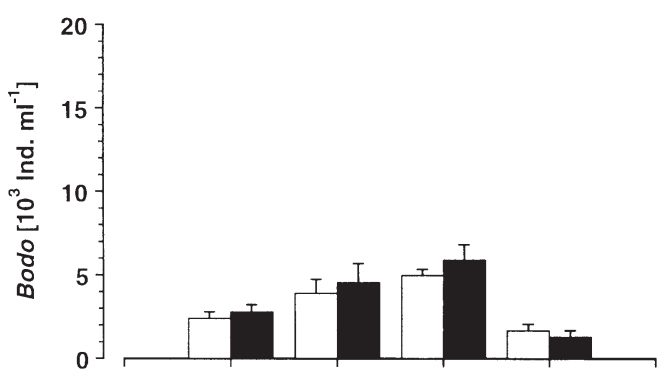

g)

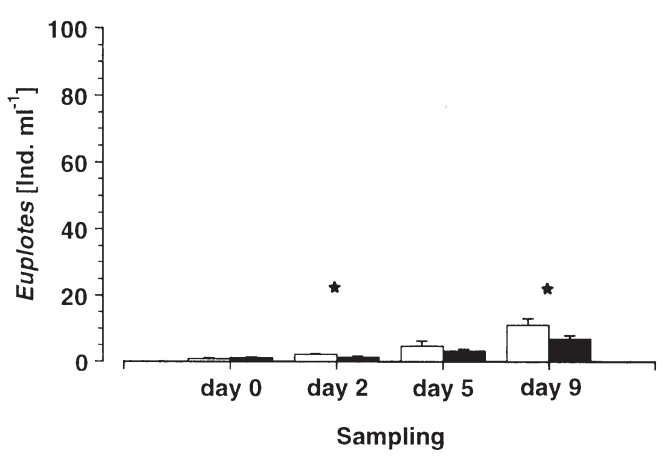

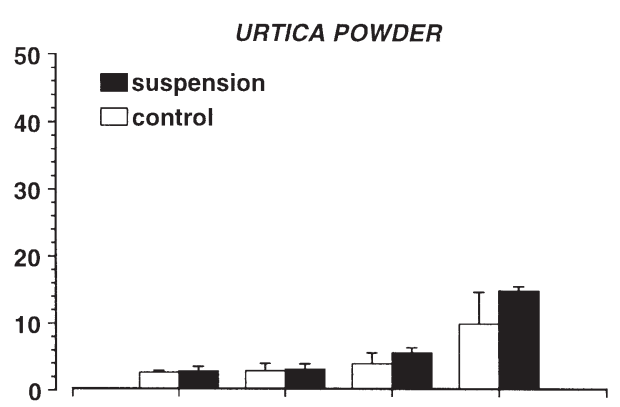

(d)

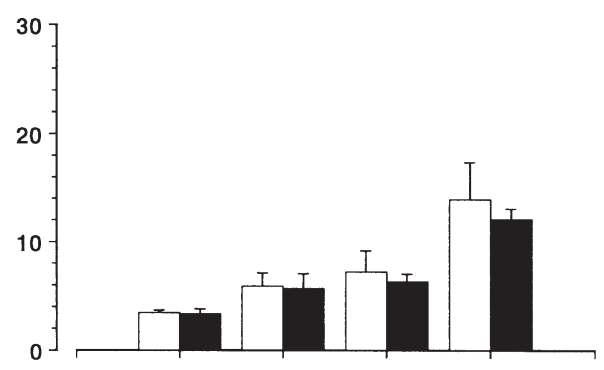

(f)

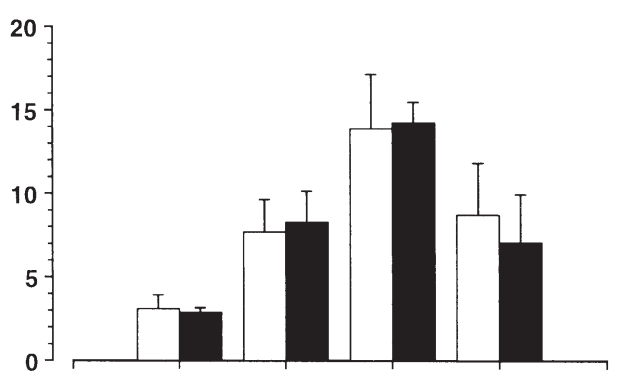

(h)

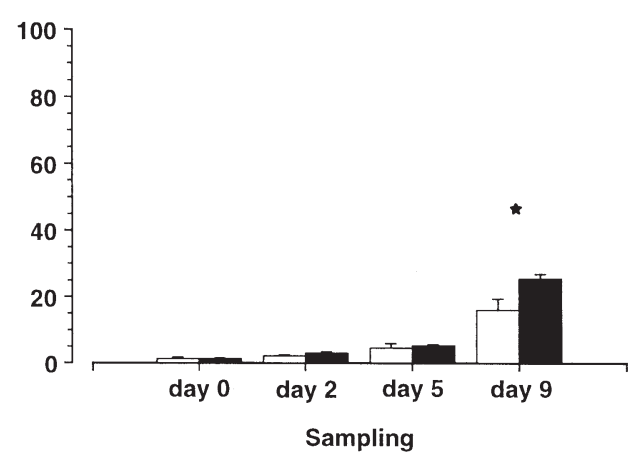

Fig. 5. Abundances of (a,b) Amphora, (c,d) bacteria, (e,f) Bodo, and $(\mathrm{g}, \mathrm{h})$ Euplotes with (Urtica powder) and without (Minimal) enrichment during the particulate enrichment experiment (mean $\pm \mathrm{SD}, \mathrm{N}=4 .{ }^{*} \mathrm{p}<0.05, t$-test, Bonferroni corrected. The scale for the $y$-axis is the same in both experimental treatments

\section{DISCUSSION}

\section{Food web structure}

The results of our experiments, especially those of the community subset experiment, support the food web structure that was derived from direct observation and literature data (e.g., Pratt \& Cairns 1985, Premke \& Arndt 2000). The abundances of bacteria and Bodo designis, but not those of Amphora coffeaeformis and Vannella platypodia, decreased in the presence of Euplotes balteatus. This is consistent with bacterivory 
Table 5. p-values for resuspension and enrichment effects over time and their interactions within the RM-ANOVA design of the particulate enrichment experiment $(\mathrm{N}=4)$, Susp.: suspension; Enr.: enrichment. Values in bold show statistically significant results

\begin{tabular}{|lrrrr|}
\hline & Amphora & Bacteria & Bodo & Euplotes \\
\hline Susp. & $\mathbf{0 . 0 0 3}$ & 0.113 & 0.465 & 0.481 \\
Enr. & $\mathbf{0 . 0 1 4}$ & $\mathbf{< . 0 0 1}$ & 0.440 & $\mathbf{< 0 . 0 0 1}$ \\
Time & $<\mathbf{0 . 0 0 1}$ & $\mathbf{< 0 . 0 0 1}$ & $<\mathbf{0 . 0 0 1}$ & $<\mathbf{0 . 0 0 1}$ \\
Susp. $\times$ Enr. & 0.277 & 0.777 & 0.580 & $<\mathbf{0 . 0 0 1}$ \\
Susp. $\times$ Time & $<\mathbf{0 . 0 0 1}$ & 0.330 & 0.593 & 0.693 \\
Enr. $\times$ Time & $\mathbf{0 . 0 0 1}$ & 0.667 & 0.787 & $<\mathbf{0 . 0 0 1}$ \\
Susp. $\times$ Enr. $\times$ Time & 0.077 & 0.305 & 0.819 & $<\mathbf{0 . 0 0 1}$ \\
\hline
\end{tabular}

Table 6. Summary of resuspension effects on final microbial abundances. No significant resuspension effects on bacteria were found. +: positive resuspension effect; - : negative effect; 0 : no significant effect; a: absent. *After $2 \mathrm{~d}$

\begin{tabular}{|c|c|c|c|c|}
\hline Group & Amphora & Bodo & Vannella & Euplotes \\
\hline \multicolumn{5}{|c|}{ Whole-community experiment } \\
\hline & + & 0 & $+^{*}$ & + \\
\hline \multicolumn{5}{|c|}{ Community subset experiment } \\
\hline -Euplotes & + & + & 0 & $\mathrm{a}$ \\
\hline+ Euplotes & 0 & 0 & + & 0 \\
\hline \multicolumn{5}{|c|}{ Particulate enrichment experiment } \\
\hline -Enrichment & + & 0 & $\mathrm{a}$ & - \\
\hline +Enrichment & 0 & 0 & $\mathrm{a}$ & + \\
\hline
\end{tabular}

and predation on Bodo by Euplotes, trophic links that are well known from previous studies. Consumption rates of up to $16 \times 10^{3}$ bacteria ind. ${ }^{-1} \mathrm{~h}^{-1}$ (Euplotes mutabilis) and up to 21 Bodo sorokini ind. ${ }^{-1} \mathrm{~h}^{-1}$ (Euplotes vannus) from prey concentrations similar to those used in our experiments have been reported (Zubkov \& Sleigh 1996, Premke \& Arndt 2000).

Bodo designis and Vannella platypodia are also bacterivores (Pratt \& Cairns 1985, Page \& Siemensma 1991) and were expected to reduce bacterial abundances in the absence of Euplotes. However, we did not find evidence for this interaction. A possible explanation is that Vannella fed on Bodo, in addition to bacteria. Thus, Vannella would have contributed less to bacterivory, while keeping abundances of bacterivorous Bodo relatively low. Predation on heterotrophic protists by Vannella has not been studied, but it has been reported from other rhizopods (e.g., Bovee 1960), and predation on Bodo by Vannella has occasionally been observed in crude cultures (Garstecki pers. obs.). Although Vannella does not appear to be an efficient flagellate grazer, the interaction may explain the crash in Bodo abundance at the end of the whole-community experiment when abundance of Vannella was exceptionally high.
In addition to trophic interactions between microbial populations, the links between experimental enrichment and the microbial food web need to be considered. Amphora coffeaeformis was not favoured by enrichment. Particulate enrichment with Urtica powder, a particulate phytodetritus surrogate, enhanced population growth of all heterotrophic protists (Table 5), but it is not clear at which trophic level it was incorporated into the microbial food web. Bacterial utilisation after enzymatic breakdown, direct protistan detritivory (Posch \& Arndt 1996) and a combination of both are possible. The temporal resolution of our data set is not sufficient to distinguish between these trophic links or between mechanisms of liquid enrichment utilisation. Nevertheless, our data confirm the predicted general food web structure. Against the background of this structure, effects of resuspension on individual trophic links can be discussed.

\section{Resuspension effects on Amphora coffeaeformis and bacteria}

De Jonge \& van Beusekom (1995) assumed that suspended microphytobenthos grow as efficiently as sedimented ones. However, resuspension increased the abundance of Amphora during all of our experiments. Since enrichment was identical in resuspended and control microcosms in the first 2 experiments, and since resuspension tripled final diatom abundances in microcosms without enrichment, it is unlikely that there were insufficient nutrients to support diatom growth in the static controls. Rather, the ability of Amphora to utilise the nutrients present in the medium was likely higher when they were in suspension. The more efficient nutrient utilisation could be due to increased mean nutrient supply to individual cells in a population dispersed by resuspension (Bothwell 1989) or to reduced transport limitation of nutrient supply to suspended cells. While similar effects of water motion on phytolankton nutrient uptake and growth are well established (Aguilera et al. 1994, Reynolds 1994, Estrada \& Berdalet 1997), they have not yet been discussed with respect to resuspension effects on microphytobenthos.

Increased light attenuation after resuspension may decrease microphytobenthos primary production in natural systems (Hellström 1991, MacIntyre \& Cullen 1996). However, the net resuspension effect on water column primary production is also influenced by decreased light attenutation due to reduced selfshading, and nutrient and chlorophyll a fluxes from the sediment, and is thus not necessarily negative (Gabrielson \& Lukatelich 1985, MacIntyre \& Cullen 1996). Light attenuation by suspended particulates 
was generally taken into account in our experimental design because sediment was included in the microcosms. Nevertheless, growth of Amphora appeared not to be reduced due to insufficient light in suspension. It remains to be seen whether enhanced growth due to better nutrient access in suspension is a general phenomenon of resuspended benthic algae, and how different light regimens affect the response of these algae and further effects on the microbial food web.

The failure to detect a positive resuspension effect on bacterial gross growth (Fig. 2d) and abundance during our experiments may partly be due to the limited accuracy of our methodology. However, planktonic bacteria did not show direct effects of experimental turbulence and mixing in previous studies, and solitary bacterial cells are considered too small to benefit directly from water motion (Moeseneder \& Herndl 1995, Karp-Boss et al. 1996, Peters et al. 1998). Therefore, it is unlikely that enhanced bacterial utlisation of dissolved organic matter and increased bacterial gross growth rates in suspension contributed to the positive resuspension effects that were observed at higher trophic levels in our experimental food web.

\section{Resuspension effects on protistan population dynamics}

Resuspension enhanced the population growth of Euplotes balteatus in all enriched experiments except the minimal ASW medium, where there was a significant decline. This pattern is consistent with improved food access or increased growth efficiency of Euplotes in suspension when food is generally abundant and impaired food access or reduced growth efficiency when food is scarce. The results of the community subset experiment support the food accessibility hypothesis: the increase in the abundance of Bodo designis in resuspended versus control treatments disappeared when Euplotes was present. A similar, but non-significant trend was found for Euplotes interactions with bacterial abundance: in the community subset experiment, there was lower abundance in resuspension only when ciliates were present. In the other experiments where ciliates were present in all treatments, there was again the pattern of higher ciliate but lower bacterial abundance in resuspended microcosms. Only in the unenriched treatments of the particulate enrichment experiment did this pattern not hold. The higher grazing impact of Euplotes in suspension was not due to increased prey abundance and higher functional responses alone because numerical predator/prey ratios were always higher in suspension, and bacterial abundances became lower in suspension than in the controls after $5 \mathrm{~d}$. Suspended, dispersed prey may be more accessible for an average individual in a filterfeeding Euplotes population than discrete, surfaceassociated food patches, and mixing may increase prey encouter rates (Shimeta et al. 1995, Peters et al. 1998).

The data of the particulate enrichment experiment agree with a trophic mechanism mediating resuspension effects on population dynamics of Euplotes. The negative resuspension effect on ciliate growth in the minimal ASW group shows that this mechanism operates only above a certain food concentration and may be non-existent at low food supply in the field. Since abundances of bacteria and Bodo were low without enrichment, resuspension and dispersal may have decreased prey encounter rates in this group until grazing in suspension was less efficient than grazing from patches of sedimented prey in the non-resuspended treatment. Zubkov \& Sleigh (1996) reported a drop of gross growth efficiency from $43 \%$ to $20 \%$ in Euplotes mutabilis as bacterial food concentration was decreased from $30 \times 10^{6} \mathrm{ml}^{-1}$ to $6 \times 10^{6} \mathrm{ml}^{-1}$. The relevance of food supply for ciliate growth during the particulate enrichment experiment is highlighted by positive correlations of bacterial and ciliate abundances that are consistent with bottom-up control of Euplotes balteatus by bacterial food supply.

The effects of resuspension on trophic links involving Euplotes balteatus cannot be too widely generalised because they depend partly on the feeding ecology of this ciliate. However, another hypotrich ciliate (Aspidisca sp.) also responded positively to sediment disturbance in earlier experiments (Alongi 1985). The rhizopod Vannella platypodia and the flagellate Bodo designis responded positively to resuspension during our experiments although they have a surface-associated feeding mode. They were probably associated with aggregates in suspension, as has been observed both in the field and in the laboratory (Artolozaga et al. 1997, Zimmermann-Timm et al. 1998). Trophic mechanisms of resuspension effects involving Vannella and Bodo are difficult to discern because they were always inoculated together, or together with Euplotes in the case of Bodo in the particulate enrichment experiment. The rhizopods were positively correlated to bacteria and Bodo in the community subset experiment when Euplotes was absent. This may imply bottom-up control of Vannella by bacterial and possibly flagellate food supply, and a similar mechanism to that in Euplotes leading to improved food access in suspension. Gross growth rates of Bodo were much higher in suspension, but most of the surplus biomass in resuspended microcosms was consumed by Euplotes when the ciliate was present. Thus, Bodo had a higher biomass turnover in suspension and was a more efficient link in terms of carbon flow. Since Euplotes and Vannella were the top predators in our food web and 
Amphora was not consumed, biomass accumulated in their populations towards the end of the experiments. If higher trophic levels had been present in the microcosms, biomass turnover of Amphora, Euplotes, and Vannella might have increased in suspension similar to that of Bodo. This would have resulted in enhanced carbon flow through the experimental food web.

Our experimental design was focused on the effects of resuspension and mixing effects on trophic interactions and population dynamics in a model microbial food web. Different benthic species may react differently to resuspension, but the organisms used are major components of the microbial food web in coastal Baltic sediments (Garstecki et al. 2000) and have all been found associated with particulates in the water column (Zimmermann-Timm et al. 1998). Sediment concentrations, initial abundances and light availability were set at levels close to field conditions. Although the experimental enrichment levels may have been higher than the organic input to the water column during natural resuspension events, an increase of organic carbon and nutrient concentrations is one of their consequences: substantial stimulations of bacterial population growth by dissolved and particulate carbon inputs from the benthos have been found in various field and laboratory studies (Wainright 1987, Ritzrau \& Graf 1992, Hopkinson et al. 1998). Wainright (1987) also reported increased protozoan community biovolume after addition of resuspended material, and Ogilvie \& Mitchell (1998) detected nutrient-mediated positive effects of sediment resuspension on phytoplankton.

In contrast to the focus on transport effects in the abovementioned studies, our experiment focused on the impact of mixing and suspension at a given nutrient and carbon input. The impact of these processes on resuspended benthic microbial food webs has not yet been studied, but effects of mixing and turbulence on planktonic microbial food web interactions have been addressed (Peters \& Gross 1994, Shimeta et al. 1995, Peters et al. 1996, 1998). Although laminar shear was not quantified in our experiments, the designs of our experiments and the plankton studies both included mixing and dispersal, and can be compared with respect to their effects. Shimeta et al. (1995) found increased clearance rates in cultures of the choanoflagellate Monosiga sp. and the heliozoon Ciliophrys marina but decreased clearance rates in the tintinnid ciliate Helicostomella sp. when they were subjected to laminar shear below the turbulence microscale. They hypothesised that non-motile protists and weak swimmers would benefit most from increased turbulence and mixing, which is in agreement with the pronounced growth enhancement of the rhizopod Vannella during our experiments. Peters et al. (1998) reported bacterial net growth enhancement under turbulent conditions due to shifts of food size spectra of planktonic grazers towards larger prey. Consistent with this result, estimated consumption rates of Bodo designis by Euplotes balteatus were higher in suspension during our community subset experiment, but the negative effect of protistan grazers on bacterial abundance was still stronger in suspension. Although turbulence did not increase individual grazing rates of the heterotrophic flagellate Paraphysomonas imperforata during laboratory experiments, enhanced growth rate, decreased mean cell size and possibly behavioural adaptations resulted in a higher bacterial consumption of the flagellate population under turbulent conditions (Peters et al. 1996). Similar net effects were found in a natural nanoplankton assemblage (Peters \& Gross 1994).

Our results show that mixing during resuspension events may also have profound effects on the dynamics of resuspended benthic microbial food webs. The subsidiary energy input by resuspension and mixing may increase gross growth rates and consumption rates by higher trophic levels. This may result in a higher carbon turnover of benthic microbial food webs in shallow ecosystems.

Acknowledgements. This study is a partial fulfillment of the $\mathrm{PhD}$ requirements of T.G. Part of it was done within the interdisciplinary 'Ökobod' project supported by the German Federal Ministry of Education and Research. We wish to thank our colleagues from the project, H. Hillebrand from the Institut für Meereskunde, University of Kiel, who kindly provided the Amphora culture, and 3 anonymous reviewers who helped to improve the manuscript.

\section{LITERATURE CITED}

Aguilera J, Jimenez C, Rodriguez-Maroto JM, Niell FX (1994) Influence of subsidiary energy on growth of Dunaliella viridis Teodorescu: the role of extra energy in algal growth. J Appl Ecol 6:323-330

Alongi DM (1985) Effect of physical disturbance on population dynamics and trophic interactions among microbes and meiofauna. J Mar Res 43:351-364

Arfi R, Bouvy M (1995) Size, composition and distribution of particles related to wind-induced resuspension in a shallow tropical lagoon. J Plankton Res 17:557-574

Artolozaga I, Santamaria E, Lopez A, Ayo B, Irriberri J (1997) Succession of bacterivorous protists on laboratory-made marine snow. J Plankton Res 19:1429-1440

Bothwell ML (1989) Phosphorous-limited growth dynamics of lotic periphytic diatom communities: areal biomass and cellular growth rate responses. Can J Fish Aquat Sci 46: 1293-1301

Bovee EC (1960) Studies of feeding behavior of amoebas. I. Ingestion of thecate rhizopods and flagellates by verrucosid amebas, particularly Thecamoeba sphaeronucleolus. J Protozool 7:55-60

Caron DA (1993) Enrichment, isolation, and culture of freeliving heterotrophic flagellates. In: Kemp PF, Sherr BF, 
Sherr EB et al. (eds) Handbook of methods in aquatic microbial ecology. Lewis Publishers, Boca Raton, p 77-89

De Jonge VN, Van Beusekom JEE (1992) Contribution of resuspended microphybenthos to total phytoplankton in the Ems estuary and its possible role for grazers. Neth J Sea Res 30:91-105

De Jonge VN, Van Beusekom JEE (1995) Wind- and tideinduced resuspension of sediment and microphytobenthos from tidal flats in the Ems estuary. Limnol Oceanogr 40: $766-778$

Estrada M, Berdalet E (1997) Phytoplankton in a turbulent world. Sci Mar 61(Suppl 1):125-140

Gabrielson JO, Lukatelich RJ (1985) Wind-related resuspension of sediments in the Peel-Harvey estuarine system. Estuar Coast Shelf Sci 20:135-145

Garstecki T, Arndt H (2000) Seasonal abundances and community structure of benthic rhizopods in shallow lagoons of the southern Baltic Sea. Eur J Protistol 36:103-115

Garstecki T, Verhoeven R, Wickham SA, Arndt H (2000) Benthic-pelagic coupling: a comparison of the community structure of benthic and pelagic heterotrophic protists in shallow inlets of the Southern Baltic. Freshw Biol 45: $147-168$

Hellström T (1991) The effect of resuspension on algal production in a shallow lake. Hydrobiologia 213:183-190

Hopkinson CS Jr, Giblin AE, Garritt RH, Tucker J, Hullar MAJ (1998) Influence of the benthos on growth of planktonic estuarine bacteria. Aquat Microb Ecol 16:109-118

Jugnia LB, Tadonleke RD, Sime-Ngando T, Foto SM, Kemka N (1998) Short-term variations in the abundance and cell volume of bacterioplankton in an artificial tropical lake. Hydrobiologia 385:113-119

Karp-Boss L, Boss E, Jumars PA (1996) Nutrient fluxes to planktonic osmotrophs in the presence of fluid motion. Oceanogr Mar Biol Annu Rev 34:71-107

Kristensen P, Sondergaard M, Jeppesen E (1992) Resuspension in a shallow lake. Hydrobiologia 228:101-109

MacIntyre HL, Cullen JJ (1996) Primary production by suspended and benthic microalgae in a turbid estuary: timescales of variability in San Antonio Bay, Texas. Mar Ecol Prog Ser 145:245-268

Moeseneder MM, Herndl GJ (1995) Influence of turbulence on bacterial production in the sea. Limnol Oceanogr 40: 1466-1473

Ogilvie BG, Mitchell SF (1998) Does sediment resuspension have persistent effects on phytoplankton? Experimental studies in three shallow lakes. Freshw Biol 40:51-63

Padišak J, Toth LG, Rajczy M (1990) Stir-up effect of wind on a more or less stratified shallow lake phytoplankton community, Lake Balaton, Hungary. Hydrobiologia 191:249-254

Page FC, Siemensma FJ (1991) Nackte Rhizopoda und Heliozoea. Gustav Fischer Verlag, Stuttgart

Peters F, Gross T (1994) Increased grazing rates of micro-

Editorial responsibility: Robert Sanders,

Philadelphia, Pennsylvania, USA plankton in response to small-scale turbulence. Mar Ecol Prog Ser 115:299-307

Peters F, Choi JW, Gross T (1996) Paraphysomonas imperforata (Protista, Chrysomonadida) under different turbulence levels: feeding, physiology and energetics. Mar Ecol Prog Ser 134:235-245

Peters F, Marrase C, Gasol JM, Sala MM, Arin L (1998) Effects of turbulence on bacterial growth mediated through food web interactions. Mar Ecol Prog Ser 172:293-303

Posch T, Arndt H (1996) Uptake of sub-micrometre- and micrometre-sized detrital particles by bacterivorous and omnivorous ciliates. Aquat Microb Ecol 10:45-53

Pratt JR, Cairns J Jr (1985) Functional groups in the protozoa: roles in different ecosystems. J Protozool 32:415-423

Premke K, Arndt H (2000) Predation on heterotrophic flagellates by protists: food selectivity determined using a livestaining technique. Arch Hydrobiol 150:17-28

Reynolds CS (1994) The role of fluid motion in the ecology of phytoplankton. In: Giller PS, Hildrew AG, Raffaelli D (eds) Aquatic ecology: scale, pattern and process. Blackwell Scientific Publications, Oxford, p 141-187

Reynolds CS (1996) Phosphorus recycling in lakes: evidence from large enclosures for the importance of shallow sediments. Freshw Biol 35:423-445

Ritzrau W, Graf G (1992) Increase of microbial biomass in the benthic turbidity zone of Kiel Bight after resuspension by a storm event. Limnol Oceanogr 37:1081-1086

Shaffer GP, Sullivan MJ (1988) Water column productivity attributable to displaced benthic diatoms in well-mixed shallow estuaries. J Phycol 24:132-140

Sherr EB, Caron DA, Sherr BF (1993) Staining of heterotrophic protists for visualization via epifluorescence microscopy. In: Kemp PF, Sherr BF, Sherr EB (eds) Handbook of methods in aquatic microbial ecology. Lewis Publishers, Boca Raton, p 213-227

Shimeta J, Sisson JD (1999) Taxon-specific tidal resuspension of protists into the subtidal benthic boundary layer of a coastal embayment. Mar Ecol Prog Ser 177:51-62

Shimeta J, Jumars PA, Lessard EJ (1995) Influences of turbulence on suspension feeding by planktonic protozoa: experiments in laminar shear fields. Limnol Oceanogr 40: $845-859$

Utermöhl H (1958) Zur Vervollkommnung der quantitativen Phytoplankton-Methodik. Mitt Int Ver Limnol 9:1-38

Wainright SC (1987) Stimulation of heterotrophic microplankton production by resuspended marine sediments. Science 238:1710-1711

Zimmermann-Timm H, Holst H, Müller S (1998) Seasonal dynamics of aggregates and their typical biocoenosis in the Elbe estuary. Estuaries 21:613-621

Zubkov MV, Sleigh MA (1996) Bacterivory by the ciliate Euplotes in different states of hunger. FEMS Microbiol Ecol 20:137-147

Submitted: December 8, 2000; Accepted: July 13, 2001

Proofs received from author(s): September 12, 2001 